\title{
ダム管理を含む上下流一貫の 分布型融雪流出モデルの研究 \\ UPSTREAM AND DOWNSTREAM CONSISTENT DISTRIBUTED SNOWMELT RUNOFF MODEL INCLUDING RESERVOIR REGULATION
}

\author{
宮下文夫 ${ }^{1} \cdot$ 陸 旻晈 ${ }^{2} \cdot{\text { 佐藤健太 }{ }^{3} \text { ・ 早川典生 }}^{4}$ \\ Fumio MIYASHITA, Minjiao LU, Kenta SATOU and Norio HAYAKAWA \\ 1正会員（社）北陸建設弘済会企画広報部（ $干$ 950-0197 新潟市亀田工業団地 2-3-4） \\ 2正会員 工博 長岡技術科学大学助教授 環境・建設系（T 940-2188 長岡市上富岡町 1603-1） \\ 3非会員 工修 ユニオンツール（株）システム開発課（† 940-1104 長岡市摂田屋町字外川 2706-6) \\ 4フェロー会員 Ph. D. 長岡技術科学大学名誉教授（† 940-2124 長岡市希望ヶ丘 1-158-236)
}

\begin{abstract}
The purpose of this study is to develop a upstream and downstream consistent distributed snowmelt runoff model including reservoir regulation, and carry out runoff analysis in the Sagurikawa River basin, which includes a reservoir. It aims at realizing reservoir operation in consideration of the action of the water in a basin, and grasping the amount of water resources of study basin by using the upstream and downstream consistent distributed snowmelt runoff model including reservoir regulation. The delineation of channel network used by the distributed hydrological model was created, and the upstream and downstream consistent distributed snowmelt runoff model includes reservoir regulation was developed. In this model, since the whole basin can be taken into account, it is possible to take various dam managements into consideration.
\end{abstract}

Key Words : water resources, distributed snowmelt runoff model, reservoir regulation

1.はじめに

日本国内には約 3,000 を超えるダムがある. その設置 目的は上水道水, 工業用水, 発電, あるいは洪水調節な ぞ多目的であるが，その管理は安全かつ適切に行われな ければならない. ダム管理は時代の変遷にともない洪水 や利水・環境に対して多様なニーズが要求される傾向に ある.こうした要求に対処するためには，学術的に裏付 けられた洪水予測手法を導く必要があるが，現状では過 去の経験に基づいた対応がなされている. より合理的に 問題に対処するためには, 流出モデルを利用することが 必要である．また，雪は重要な水資源となっているが, その反面，融雪出水などによる被害発生の要因にもなっ ている.このような雪の有効利用・融雪出水の予測は非 常に重要な課題と考えられる. しかし, 豪雪地域や山岳 地域の降雪・積雪特性を把握することは非常に困難なこ とである. したがってモデルによる再現・予測及び水資 源量の把握をする必要がある.
本研究は, 豪雪地带に位置する三国川流域を対象に水 資源量を推定し，ダム操作モデルを組み込んだ分布型融 雪流出モデルの基礎を構築することを目的とした.

\section{2. 流域概要}

三国川流域は新潟県魚沼地方の，流域面積 $140.1 \mathrm{~km}^{2}$, 標高 $1,500 \mathrm{~m} \sim 2,000 \mathrm{~m}$ 級の越後山脈を水源に, 幹川流路延 長 $23.3 \mathrm{~km}$ 一気に流下し扇状地を形成寸る急流河川で, 信濃川水系魚野川の支川である. 三国川ダム上流域の集 水面積は $76.2 \mathrm{~km}^{2}$ と小流域で, 積雪深が $4 \mathrm{~m} \sim 5 \mathrm{~m} に も$ 達す る日本有数の豪雪地帯である ${ }^{11}$.

\section{3. 流域水文情報}

水文情報として気象庁 AMeDAS 観測所, 国土交通省北陸 


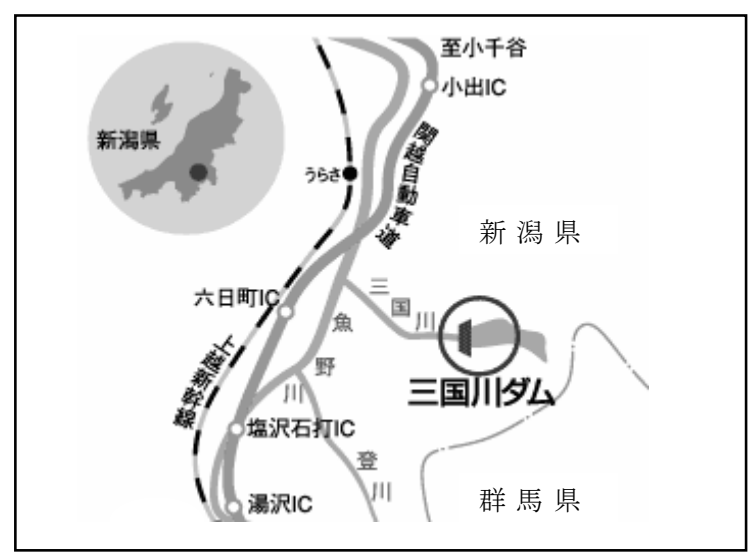

図-1 三国川流域図

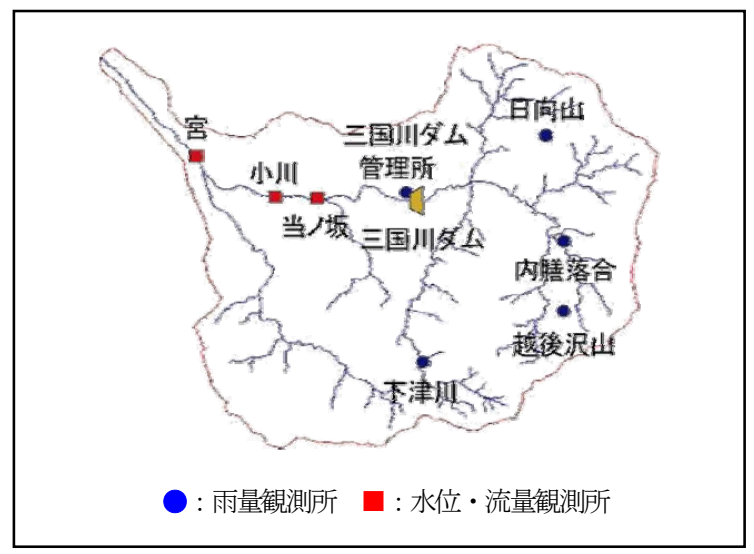

図－2 水文施設位置図

地方整備局三国川ダム管理所のデータを使用した. 図-1 に示す三国川流域には, 図-2 に示寸雨量観測所 5 箇所, 水位・流量観測所 3 箇所がある2)。しかし, 雨量観測所 5 箇所のうち 3 箇所が冬期（11月～4月）の観測を行って いないため, 通年で観測を行っている，三国川ダム管理 所と内膳落合雨量観測所の雨量データを用いる.また, 流量はダム下流の当ノ坂水位・流量観測所のデータを用 いる. 地理情報として国土地理院数值地図・50mメッシュ 標高データを使用する, 実河道データ・流域界データは 地形図からデジタイジングして作成する.

\section{4. 分布型融雪モデルの概要}

本研究で用いる分布型モデル ${ }^{3)}$ は, 流域を細分化し分 割した各メッシュで流出計算を行う。各メッシュからの 流出は河道まで集められ, 最後に河道追跡を経て流量を 得る.また，地熱による融雪量は時期的・空間的に違い があることから, 従来の分布型融雪モデルでは考慮され ていない. 本モデルでは豪雪地帯の融雪による出水量を 把握するため地熱による融雪量を推定する. 各メッシュ の気温は数值地理情報の標高データより気温減率を用い て推定する. 地表に到達寸る以前の降水は, 雨や雪, 霧 等の気象状況に左右され状況は一様ではない. 降雪は積

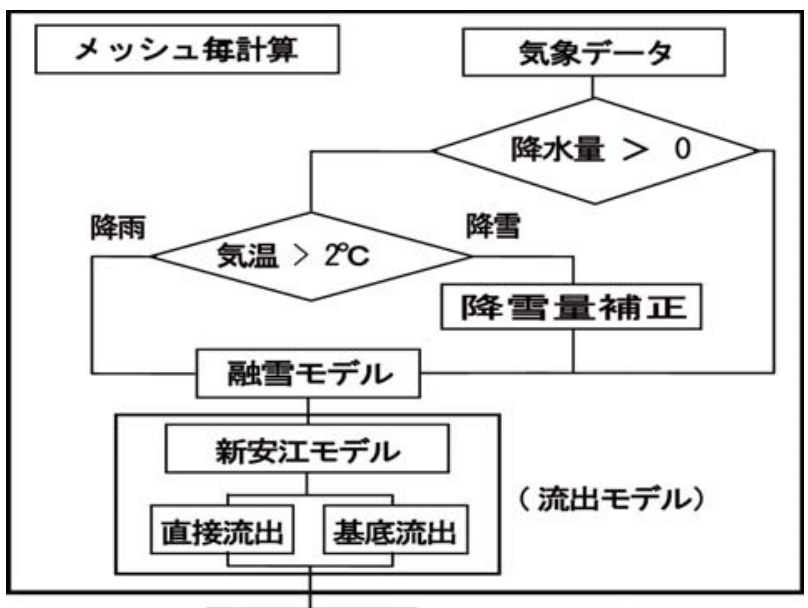

擬河道網 (流出集中経路)

Kinematic Wave Model

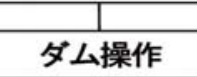

河川流量

図一３分布型融雪流出モデル

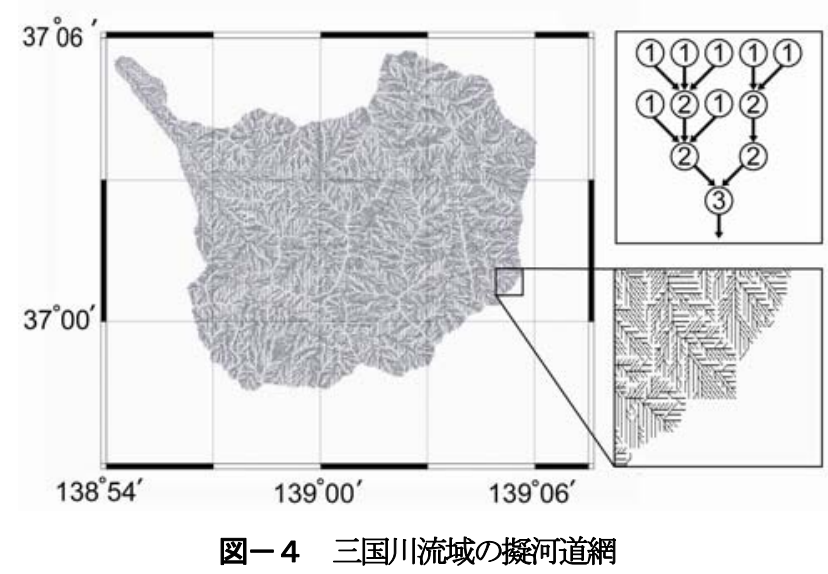

雪作用により流域に貯雪され，融雪現象により融雪水と して流出寸るため, 降水と降雪では流出過程が異なる. そのため算出された気温が $2^{\circ} \mathrm{C}$ 以下であれば降雪, $2^{\circ} \mathrm{C}$ 以 上であれば降水と判断しで，降積雪過程・融雪過程を 経て各メッシュ流出量が算出される流出モデルが啇応さ れる. 各メッシュにより算出された流出量は, 擬河道網 を介し, Kinematic Wave法により追跡計算し算出する, ダムに位置する 1 メッシュを通過する場合そのメッシュ に流入する流量をダムへの流入量として，ダム操作を行 いダム下流に流す分布型融雪流出モデル ${ }^{5)}$ を図-3 に示す.

\section{5. 擬河道網とパラメータ}

擬河道網とは仮想的な河道を算出し, 各メッシュから 流域出口までの流出集中経路を示すものである.図-4に 三国川流域の擬河道網を示す．本研究で用いる擬河道網 は $50 \mathrm{~m} \times 50 \mathrm{~m}$ メッシュ, 総メッシュ数 56,060 である. 
表-1 決定パラメータ

\begin{tabular}{|l|c|}
\hline 蒸発散係数 & 0.75 \\
\hline 地下水減衰係数 & 0.995 \\
\hline 地表水減衰係数 & 0.3 \\
\hline 最終浸透能 & 40 \\
\hline 降雪量補正係数 & 2.3 \\
\hline 降雪量標高補正係数 & 0.002 \\
\hline 地熱による融雪量 $(\mathrm{mm})$ & 1 \\
\hline
\end{tabular}

本研究では，モデル入力值の補正及びモデルパラメー タの同定により流域特性の最適化を図る. 表-1 は決定し たパラメータ值である.

\section{6. ダム操作モデルの検証}

三国川ダムの操作を組み込み㬏 7) ） その操作の影響を ダム下流に反映できる上下流一貫した分布型融雪流出モ

デルを構築するため，三国川ダム管理データの実流入 量を入力データとし, ダム操作モデルによる放流量と貯 水位を計算し，実際の放流量，貯水位との比較を行う。 三国川ダムの実管理では，10 月以降の図-5の放流量, 図-7 の貯水位ともに計算值と大きな違いが見られる.こ の理由としてメンテナンス等による人為的影響が考えら れる. ダム取水設備のメンテナンスを行う際には，貯水 位を一定の水位まで低下させるその影響によるものであ る. 本研究ではメンテナンス等の人為的な操作による影 響を取り除いた検討を行う。その結果，図一6, 図-8に 示すとおり大きな違いは見られないので, 実際のダム操 作を本研究のダム操作モデルが再現していることを確認 できた.

\section{7. ダム上流域の流出解析}

本研究では, 積雪・融雪を考慮して 11 月 1 日から翌年 10 月 31 日までの期間を 1 計算単位年とする. 図-9 は雨 量とダム流入量の実測值と分布型融雪流出モデルによる 計算結果である. ここで表す雨量データは流域平均雨量 である．実測流入量データと分布型融雪流出モデルによ る計算結果を比較すると, 全体的な傾向は再現できてい ると言える. しかし，ピーク流量が実測值に比べ計算值 は過小評価である. 要因として, 蒸発量の算出が簡易的 であること，局地的な気象状況は現状の観測点の観測デ 一タでは把握が困難であること．また，三国川上流域面 積は $76.2 \mathrm{~km}^{2}$ と小流域であるため, 1 時間間隔の雨量デー タではモデルによる再現は非常に困難である. 面的な降 水量データの取得法としてレーダ観測データが挙げられ る.しかしデータ補正が必要となるため使用は難しい. 地熱による融雪量については積雪初期に多く地熱が失わ れ積雪後期には減少傾向にあること，また，積雪層内の

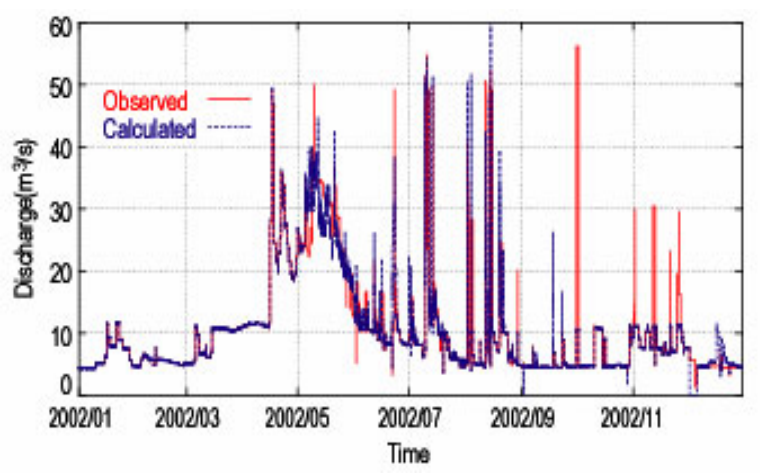

図－5 2002 ダム放流量の比較（補正前）

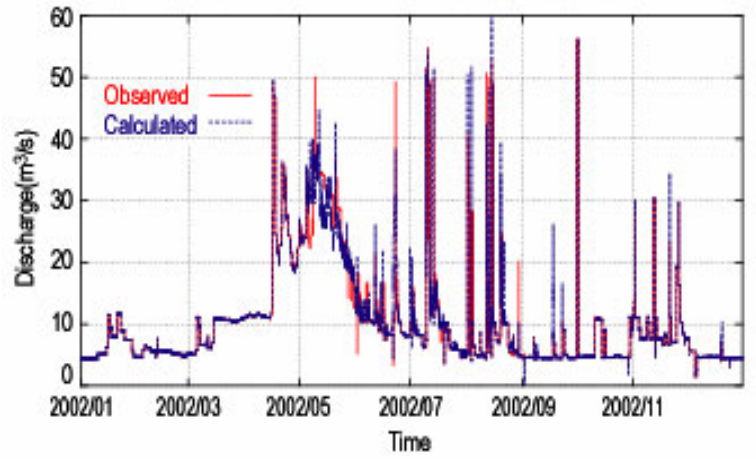

図一6 2002 ダム放流量の比較（補正後）

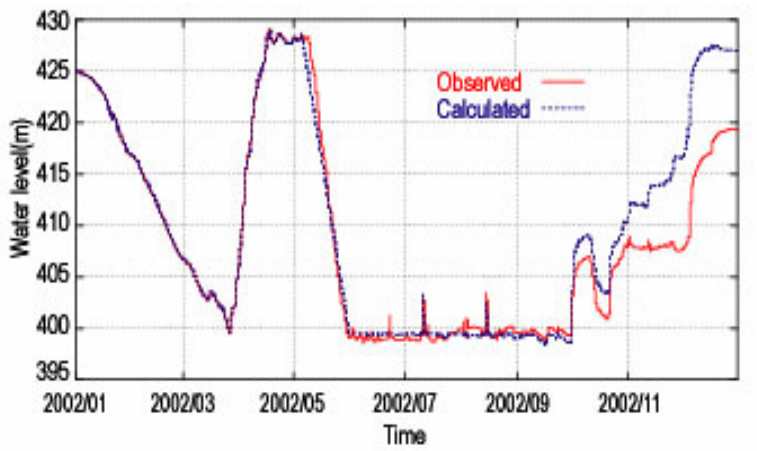

図-7 2002 ダム貯水位の比較（補正前）

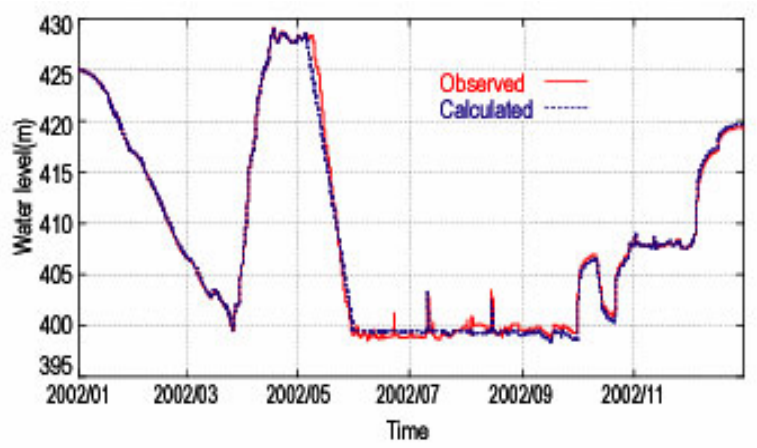

図-8 2002 ダム貯水位の比較 (補正後)

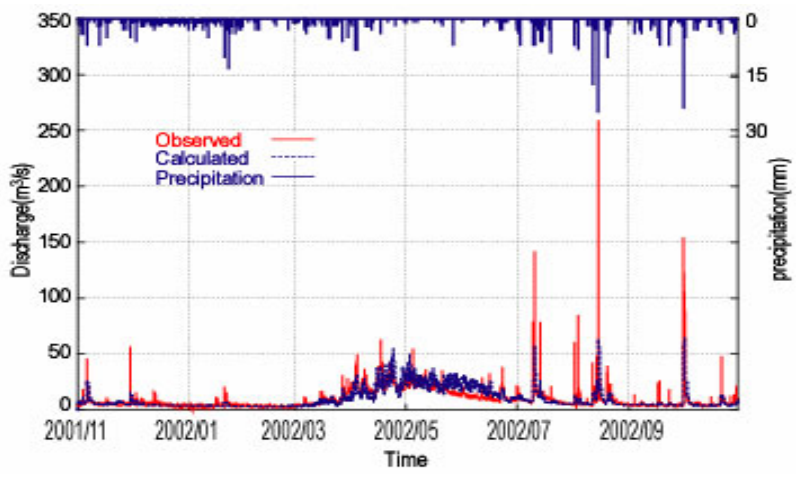

図－9 2001-2002 ダム流入量の比較 
浸透現象については, 雪量, 雪質に左右されるため時間 的に不均一である.このことが影響して実測值と計算值 に違いが出るのではと考えられる. また, 分布型融雪流 出モデル内の積雪現象は気温により判断される. 本研究 では設定気温を $2^{\circ} \mathrm{C} と し, 2^{\circ} \mathrm{C}$ 以下ならば降雪と判断され る. そのため本研究の分布型融雪流出モデルでは気温に よる依存が大きい，分布型融雪流出モデルの精度を良く するためにはより詳しく流域内の気温分布を調査寸る必 要がある.

\section{8. ダム下流域の流出解析}

図-10 は雨量と当ノ坂水位・流量観測所での実測流量 と分布型融雪流出モデルによるダム下流域の計算結果で ある.ここで表される雨量データは流域平均雨量である. 全体的な傾向としては，良く再現しているといえる。し かし, 流量ピークが実測值に比べ計算值が過小である. また, 融雪期の実測值と計算值では差が大きく計算值に よる融雪量が過大評価となっている. 誤差の要因として は, 実測データの品質照査が十分行われていないこと. また，観測所のメンテナンスも十分に行われていなかっ たことから，データの信頼性が低いことが挙げられる. ダム上流での流出解析の結果と同様に, 小流域での 1 時 間間隔の雨量データではモデルによる再現は非常に困難 である.

\section{9. ダム上流域の水資源量}

本モデルでは気温が $2^{\circ} \mathrm{C}$ 以下であれば降雪, $2^{\circ} \mathrm{C}$ 以上で あれば降水と判別している. 補正降水量は実測降水量を 補正した值であり, 真の降水量に近い值であると考えら れる. 補正前降水量 $2,067 \mathrm{~mm} /$ year に比心補正降水量 $4,716 \mathrm{~mm} /$ year は 2.28 倍の降水量を示している. 補正降 水量のうち補正降雪量は $3,232 \mathrm{~mm} /$ year とモデル内の降 水のうち $68.5 \%$ 降雪と判断している. 水資源量 4, 097mm/year は補正降水量 4, 716m/year から蒸発散 619mm/year を引いたものであり, 補正降水量の $13.1 \%$ 年 蒸発し残りが水資源量となる, この割合は三国川流域に おける雪資源の重要性を示している. 融雪量は図-11 に 示寸とおり， 2 月から融雪が始まり 4 月下旬にピークと なり 7 月中旬まで続く. 融雪期に降雨があると水害に発 展する恐れがある。一方では 2 月から 7 月まで流域のお いて貴重な水資源となっていることが分かる.

\section{0. モデルによるシミュレーション}

\section{(1) ダム放流量と貯水位}

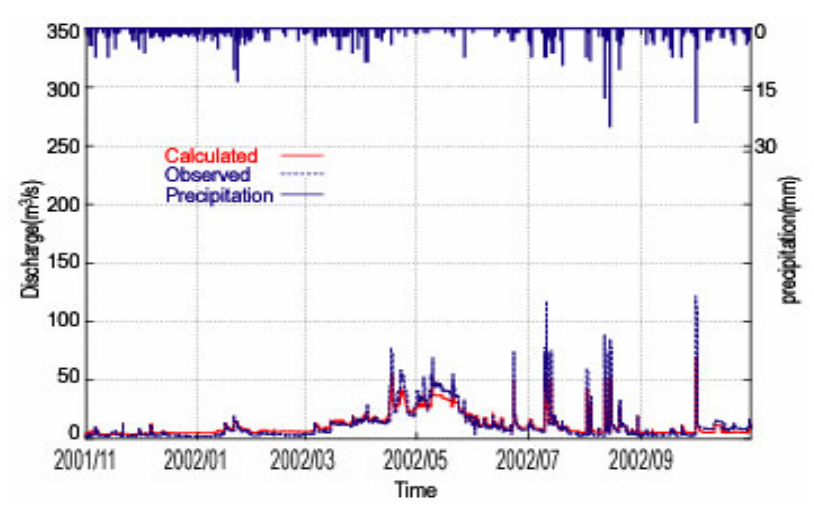

図-10 2001-2002 当ノ坂観則所での流量比較

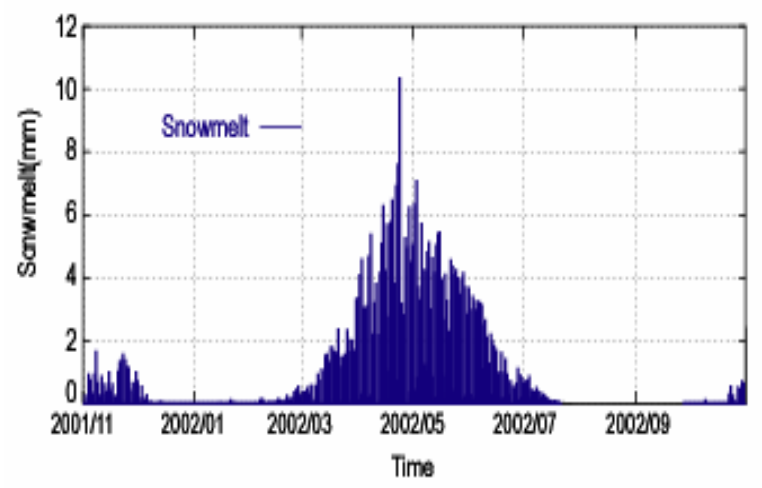

図-11 2001-2002 時間融雪量

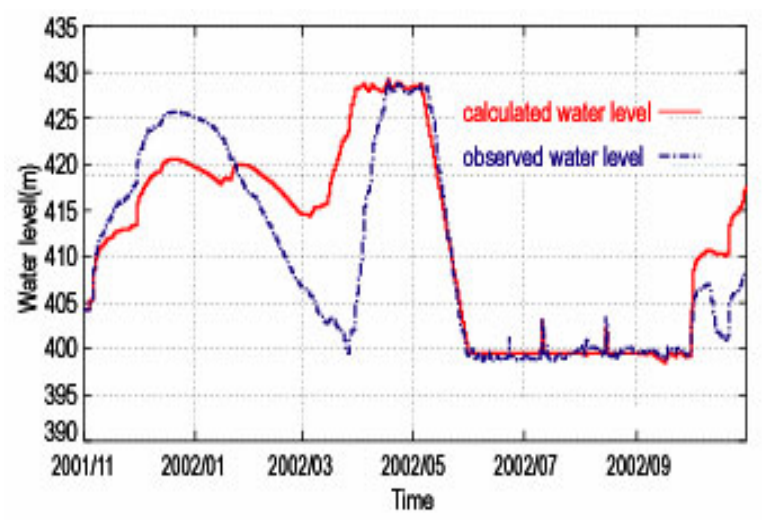

図-12 2001-2002 モデルによる貯水位

三国川ダム管理所の発電取水量は操作によるものであ り, 本研究のモデルでは発電取水量を設定できる. この 計算において発電取水量を最低の管理用取水 $1.5 \mathrm{~m}^{3} / \mathrm{s}$, 業務用取水 $3.0 \mathrm{~m}^{3} / \mathrm{s}$ に設定して計算を行った. そのため 図-12 では放流量より流入量が多いので貯水位が徐々に 上昇する結果となっている. 洪水期においてモデルは貯 水位を $399.5 \mathrm{~m}$ に一致寸るように制御している. そして 10

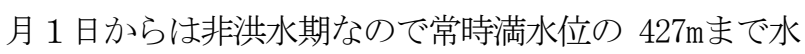
位を上昇させる管理となっている. 現状では設備の点 検・メンテナンス等による貯水位低下の操作はあるが, そのような貯水位低下を一切無視し, 流入量に対して放 流量を決定している.

（2）当ノ坂水位 - 流量観測所での流量

図-13に雨量と当ノ坂水位・流量観測所での実測流量 


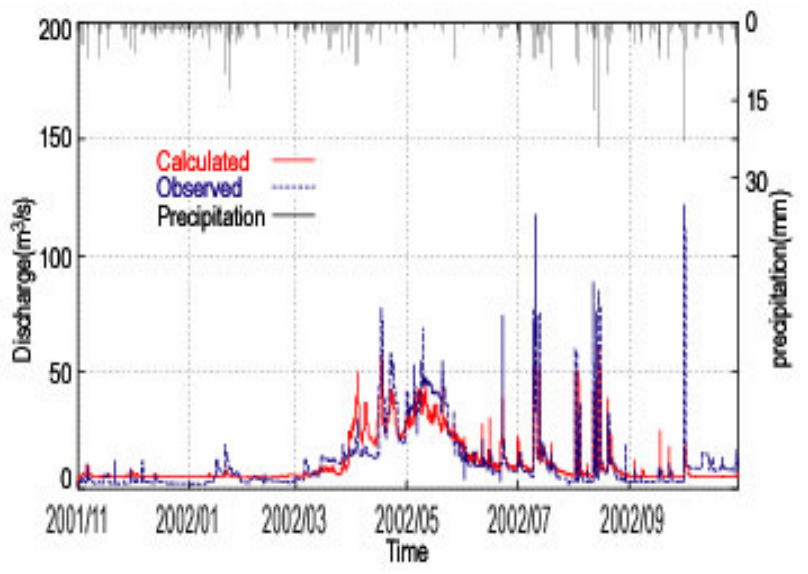

図－13 2001-2002 モデルによる当ノ坂水位・流量観測所 の流量比較

とモデルによる計算結果である. ここで表される雨量デ 一夕は流域平均雨量である. ダム上流の流出解析と同様 のことが言えるがピーク流量が実測流量に比べ計算流量 は過小評価である. 誤差の要因としてはダム上流の流出 解析と同様のことが言える.この計算では発電取水量を 実取水量と最低取水量で行っている。 この結果では発電 取水量の違いによる影響が表れている.

\section{（3）発電取水量の変化によるダム下流流量の影響}

本研究で構築したダム操作を含む上下流一貫の分布型 融雪流出モデルでは，このようにダム操作を介してダム 下流の流量を推定することが可能である。この結果では 発電取水量を最低取水量に設定して計算を行ったが，発 電取水量を変えて計算を行い，その影響がダム下流でじ のくらいあるのかを検討寸る. 最大発電として業務用取 水 $8.5 \mathrm{~m}^{3} / \mathrm{s}$ ，管理用取水 $1.5 \mathrm{~m}^{3} / \mathrm{s}$ ，合計発電取水量を 10 $\mathrm{m}^{3} / \mathrm{s}$ 基本の発電取水量とする. また, 最低発電として 業務用取水 $3.0 \mathrm{~m}^{3} / \mathrm{s}$ ，管理用取水 $1.5 \mathrm{~m}^{3} / \mathrm{s}$ ，合計発電取 水量を $4.5 \mathrm{~m}^{3} / \mathrm{s}$ を常に発電取水量とした計算の比較を 行う. 結果として図-14, 図-15, 図-16 に示寸とおり 11 月 から 3 月中旬まで最大発電取水量がパルス状になってい る.これに応じ放流量もパルス状になっている．最大発 電取水とし $10 \mathrm{~m}^{3} / \mathrm{s}$ が取水できる時は取水しているので, 貯水位は 11 月から 3 月中旬の期間に大きな違いが顕わ れている. 最小発電取水を行った場合, 発電取水量より 流入量が多いため 11 月から 3 月中旬に水位が上昇寸る. このように本研究のモデルではダムでの操作を変更して, その影響をダム下流で見ることができる

\section{（4）弾力的管理によるダム下流流量の影響}

本研究で構築したモデルでは弾力的運用を考慮するこ とができる. 以下に弾力的管理を考慮した計算と考慮し ない計算との違いを示寸. 実施期間を洪水期中の 8 月 1 日から 9 月 30 日間で, 活用水位を制限水位 $+0.7 \mathrm{~m}$ とし, 活用水位 $400.2 \mathrm{~m}$ を貯水池に貯めたら制限水位になるま で $20 \mathrm{~m}^{3} / \mathrm{s}$ 放流するというものである. 図-17 では弾

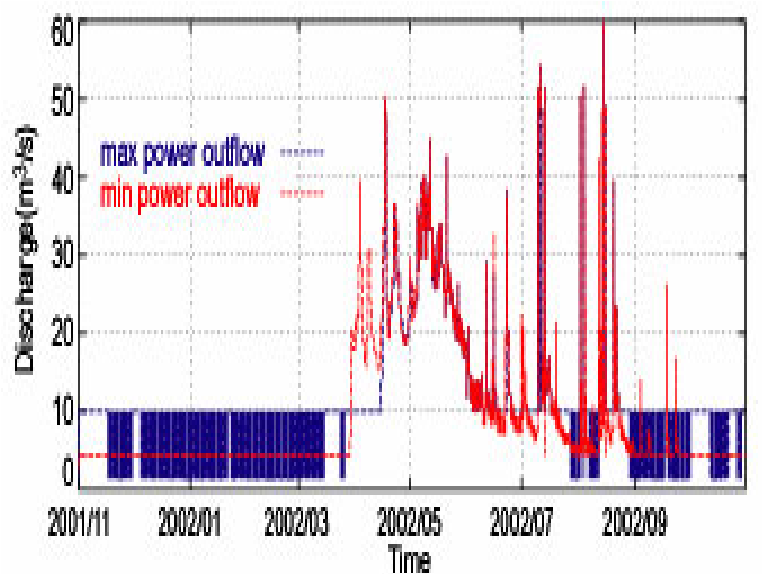

図一14 2001-2002 最大発電量と最小発電量の比較

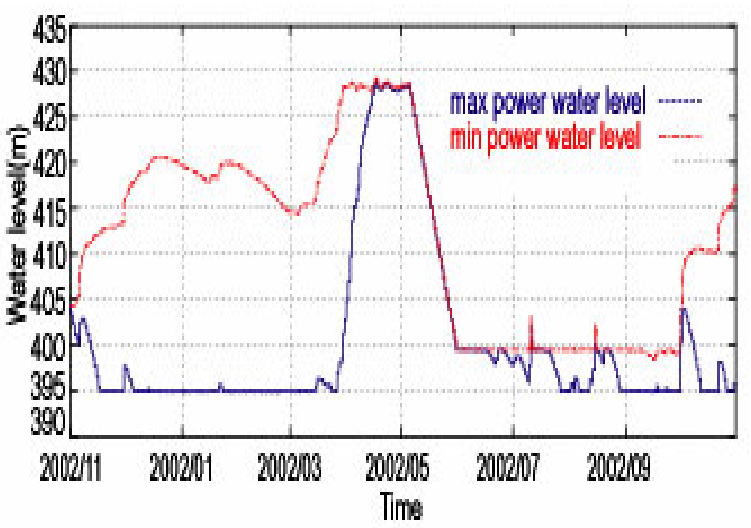

図-15 2001-2002 最大発電量と最小発電量の貯水位

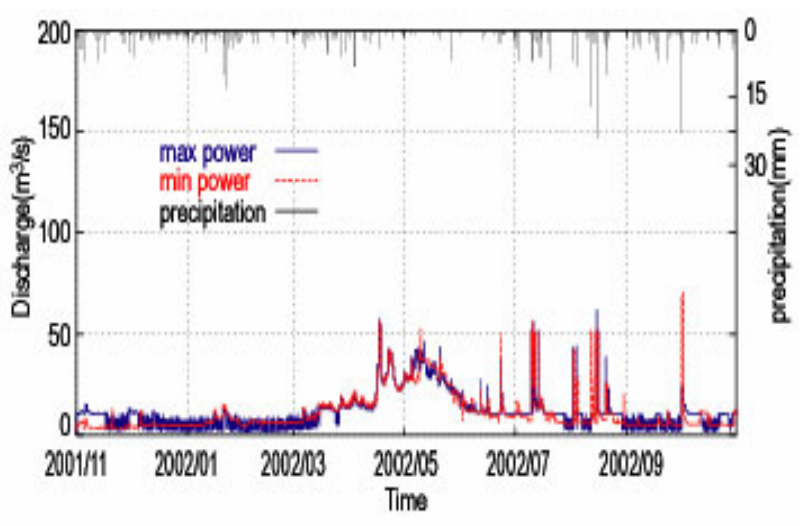

図－16 2001-2002 当ノ坂水位・流量観測所における 発電取水量による流量の影響

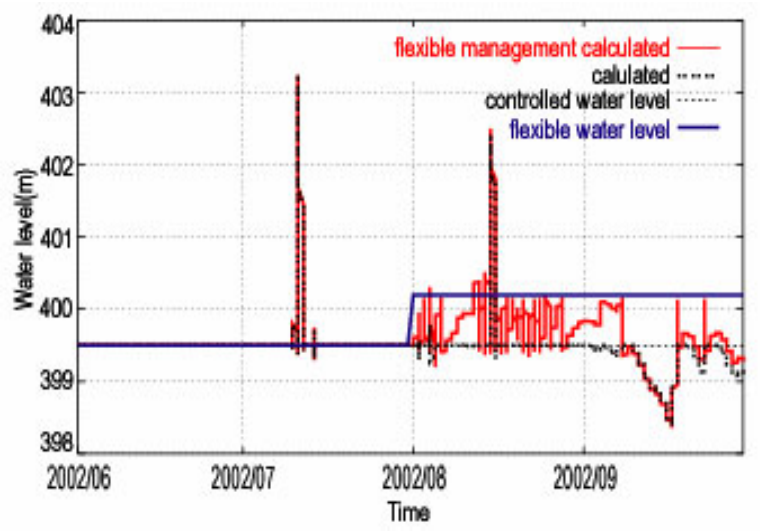

図-17 弾力的運用による貯水位 


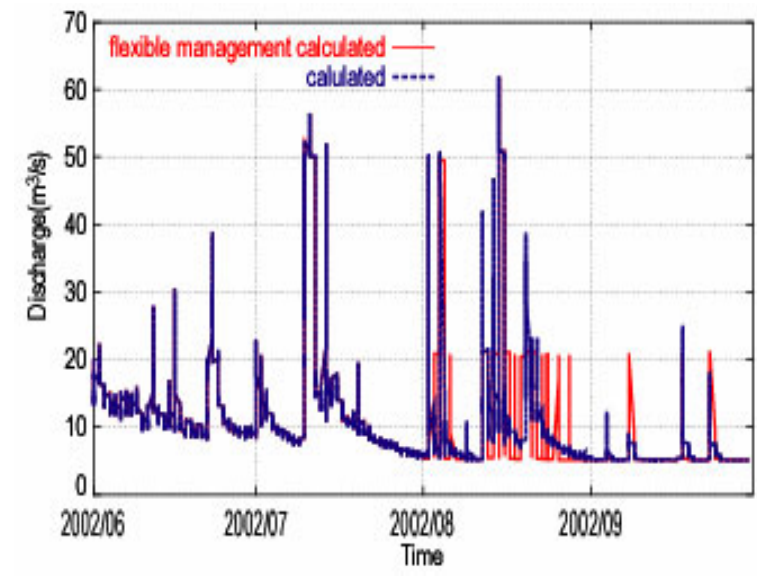

図一18 弾力的運用により事前放流をした場合流量

力的管理による貯水位の違いを示す. 弾力的管理を考慮 しない計算では制限水位である $399.5 \mathrm{~m}$ に一致するよう 制御されている. 弾力的管理を考慮した計算は $399.5 \mathrm{~m}$ 以 上の貯水位を示している. 図-17 の結果において, 貯水 位が $400.2 \mathrm{~m}$ になったので $20 \mathrm{~m}^{3} / \mathrm{s} の$ 放流を何回か行って いる. 図-18 に当ノ坂水位・流量観測所における弾力的 管理による流量の違いを示す. 弾力的管理による放流量 が顕著に表されている．このように本研究の分布型融雪 流出モデルでは弾力的管理を考慮することができる.

\section{1. 結論}

本研究ではダム調節を含んだ上下流一貫の分布型融雪 流出モデルの基礎を構築した. 三国川流域を対象にパラ メータの選定を行い，モデルに地熱による融雪を取り入 れた. 三国川流域において水資源量に関する諸量を推定 した. モデルによって得られた結果を以下に示す。

(1) 分布型融雪流出モデルで用いる三国川流域の擬河道網 を作成した。

(2) ダム調節を含んだ分布型融雪流出モデルの基礎を構築 することにより，ダム下流の流況を表現できるように なった.

（3）三国川ダム操作モデルが，ダムの実管理を再現してい ることを確認した.
(4) 年間流出高を指標として蒸発量・降雪量・降雪量標高 の補正を行い，流出解析を行った。 三国川流域におい て適用性，流量の再現性が向上した.

（5）地熱による融雪を考慮し, 融雪期における計算流出高 が実測流出高に近づいた.

(6) 三国川流域の降水量・降雨量・降雪量・蒸発量をモデ ルにより推定し，水資源量の把握を行った.

\section{2. まとめ}

ダム上下流一貫の分布型融雪モデルにより, 水資源の 高度利用, 環境に配慮した弾力的運用, 洪水予測を活用 した事前放流, ダム下流の流量管理といった, ダム操作 の適用性, 活用効果, 安全性の検証などを有効に表現で きることが示された. 今後の課題として, 流域の土地被 覆情報, 地質情報などを反映できるモデルの高精度化が 考えられる.

謝辞 : 国土交通省北陸地方整備局の関係諸機関の皆様に は多大な協力を賜った。ここに感謝の意を表す。

\section{参考文献}

1）建設省北陸地方建設局三国川ダム管理所 : 信濃川水系三国川 ダム工事誌, 1998.

2）建設省北陸地方建設局三国川ダム管理所 : 信濃川水系三国川 ダム図面集 I, 1998.

3）陸旻晈: 分布型水文情報に対応する流出モデルの開発 長岡 技術科学大学博士論文 1991 .

4) 太田岳史 : 森林内における積雪面上の純放射量の推定と表層 融雪量 水文・水資源学会 Vol. 5No. 4pp19-26 1992.

5）小池俊雄・高橋裕・吉野昭一: 積雪面積雪情報による流域積 雪水量の推定 土木学会論文集 375/II-4pp159 1985.

6）国土交通省北陸地方整備局 : 信濃川水系三国川ダム操作規則, 2002.

7）国土交通省北陸地方整備局 : 信濃川水系三国川ダム操作細則, 2002.

8）国土交通省北陸地方整備局: 三国川ダム弾力的管理試験要領, 2004.

(2005. 9. 30 受付) 